\title{
FOOD CONCENTRATION AND TEMPERATURE EFFECTS ON LIFE CYCLE CHARACTERISTICS OF TROPICAL CLADOCERA (Daphnia gessneri Herbst, Diaphanosoma sarsi Richard, Moina reticulata (Daday)): I. DEVELOPMENT TIME.
}

\author{
EIsa. R. HARDY ${ }^{1,2}$, A. DUNCAN ${ }^{2}$
}

\begin{abstract}
The effects of food concentration and temperature on embryonic and postembryonic duration of three tropical species, Daphnia gessneri $(1.5 \mathrm{~mm})$, Diaphanosoma sarsi $(1.2 \mathrm{~mm})$ and Moina reticulata $(0.8 \mathrm{~mm})$, were investigated as part of life cycle studies which included growth, body size and reproduction. These are the very first experimental studies undertaken on these species. The long-term growth experiments were performed under controlled laboratory conditions at all combinations of temperature $\left(22^{\circ} \mathrm{C}, 27^{\circ} \mathrm{C}\right.$ and $\left.32^{\prime \prime} \mathrm{C}\right)$ and constant food concentration $(0.03,0.05,0.10,0.25,0.50$ and $1.00 \mathrm{mgC} / \mathrm{L})$ of the unicellular green alga Scenedesmus acutus. Animals were examined twice daily throughout their life cycle from the neonate to third adult instar. In all three species, temperature exerted the most powerful influence on embryonic duration but there was also a smaller food effect. In D. gessneri, postembryonic durations remained more or less the same at food levels $0.25 \mathrm{mgC} / \mathrm{L}$ but were influenced by temperature. At food concentrations of $0.1 \mathrm{mgC} / \mathrm{L}$ or lower, postembryonic durations became increasingly prolonged, particularly at high temperatures. This threshold concentration is affected by temperature: in D. gessneri, it was $0.1 \mathrm{mgC} / \mathrm{L}$ at $22^{\circ} \mathrm{C}$ and $27^{\circ} \mathrm{C}$ but higher at $32^{\circ} \mathrm{C}$ (between 0.25 and $0.50 \mathrm{mgC} / \mathrm{L}$ ). At the same temperature of $27^{\circ} \mathrm{C}$, the food threshold level varied between species: it was higher $(0.25 \mathrm{mgC} / \mathrm{L})$ for $D$. sarsi and lower $(0.05 \mathrm{mgC} / \mathrm{L})$ for $M$. reticulata compared with $D$. gessneri $(0.1 \mathrm{mgC} / \mathrm{L})$. In both embryonic and postembryonic durations there is a body size effect as the absolute durations were longest in the largest species and shortest in the smallest species In all three species, prolongation of postembryonic duration at combinations of high temperature and lowered food levels was accompanied by increased number of juvenile instars.
\end{abstract}

Key- words: Daphnia gessneri, Diaphanosoma sarsi, Moina reticulata; Tropical; Food concentration-temperature experiments; Embryonic $\left(D_{v}\right) ;$ Postembryonic development $\left(D_{j}\right)$; Ratio $\left(D_{j} /\right.$ $D_{c}$; Food Threshold.

Efeitos da Temperatura e Concentração de Alimento na Historia de Vida de Tropical Cladocera (Daphnia Gessneri Herbst,Diaphanosoma Sarsi Richard, Moina reticulata Daday,)) I. Tempo de desenvolvimento.

RESUMO - Os efeitos de temperatura e concentração de alimento na duração do desenvolvimento embrionário e postembrionário de três espécies tropicais, Daphnia gessneri $(1.5 \mathrm{~mm})$, Diaphanosoma sarsi $(1.2 \mathrm{~mm})$ and Moina reticulata $(0.8 \mathrm{~mm})$, foram investigados como parte dos estudos de ciclo de vida incluindo crescimento, tamanho do corpo e reprodução. Estes são os primeiros estudos experimentais realizados com estas espécies. Os experimentos de crescimento de longa duração foram feitos em condições controladas de laboratório em todas as combinações de temperature $\left(22^{\circ} \mathrm{C}, 27^{\circ} \mathrm{C}\right.$ e $\left.32^{\circ} \mathrm{C}\right)$ e concentração constante de alimento $(0.03$, $0.05,0.10,0.25,0.50$ and $1.00 \mathrm{mgC} / \mathrm{L}$ ) de alga verde unicelular Scenedesmus acutus. Os animais foram analisados duas vezes por dia durante o ciclo de vida desde neonata ao terceiro estádio

\footnotetext{
National Institute of Amazon Research (INPA), Department of Aquatic Biology, Manaus, Brazil, CEP 69011.

2 Department of Biology, Royal Holloway University of London, Egham, Surrey TW20 OEX, U.K.
} 
adulto. Nas três espécies, a temperatura exerceu um maior efeito no tempo do desenvolvimento embrionário mas ocorreu também um pequeno efeito de concentração de alimento. Em Daphnia gessneri, a duração postembriônica permaneceu mais ou menos a mesma na concentração de alimento de $0.25 \mathrm{mgC} / \mathrm{L}$ mas foi influenciada pela temperature. Na concentração de $0.1 \mathrm{mgC} / \mathrm{L}$ ou mais baixa, a duração postembrionária tornou-se mais prolongada, particularmente em alta temperatura. O valor absoluto do nivel crítico de concentração de alimento foi afetado pela temperatura: em D. gessneri, foi $0.1 \mathrm{mgC} / \mathrm{L}$ em $22^{\circ} \mathrm{C}$ e $27^{\circ} \mathrm{C}$ mas aumentou em $32^{\circ} \mathrm{C}$ (entre 0.25 e $0.50 \mathrm{mgC} / \mathrm{L}$ ). Na mesma temperatura de $27^{\circ} \mathrm{C}$, o nivel crítico de alimento variou entre as espécies: foi mais alta $(0.25 \mathrm{mgC} / \mathrm{L})$ para $D$. sarsi e mais baixa $(0.05 \mathrm{mgC} / \mathrm{L})$ para $M$, reticulata comparada com $D$. gessneri $(0.1 \mathrm{mgC} / \mathrm{L})$. Em ambos, no desenvolvimento embrionário e postembrionário ocorreu o efeito do tamanho do corpo visto que as duraçōes absolutas foram mais longas nas espécies maiores e mạis curtas.na espécie menor. Nas três espécies, o prolongamento do desenvolvimento postembrionário nas combinações de alta temperatura e menores concentrações de alimento foi acompanhado por aumento no número de estádios juvenis.

Palavras chaves: Daphnia gessneri, Diaphanosoma sarsi, Moina reticulata; Tropical; Experimentos; Temperatura e concentração de alimento; Embrionico $\left(D_{v}\right)$; Postembrionico $\left(D_{i}\right)$; Ratio $\left(\mathrm{D}_{\mathrm{e}} / \mathrm{D}_{\mathrm{j}}\right)$; Nível crítico de alimento.

\section{INTRODUCTION}

It has been reported many times that the duration of embryonic development in crustaceans is a function of temperature only (INGLE et al., 1937; ESSLOVA, 1959; HALL, 1964; KORINEK, 1970; MUNRO \& WHITE, 1975; review in BOTTRELL et al., 1976; MAGADZA, 1977; LEVEQUE \& SAINT-JEAN, 1983; HERZIG, 1984), whereas the duration of post-embryonic development is influenced by food level as well (HRBACKOVA-ESSLOVA, 1963; WEGLENSKA, 1971; KORINEK, 1971). Many authors have shown that cladocerans cultured at high food concentrations have a shorter duration of post-embryonic development than those cultured at low food levels (DE BERNARDI et al., 1978; GRAS \& SAINT-JEAN, 1978; LEI \& ARMITAGE, 1980; VIJVERBERG, 1980; KANKAALA \& WULFF, 1981; ROCHA, 1983; ORCUTT \& PORTER, 1984; JAYATUNGA, 1986).
Most of the published information is for temperate species only, largely Daphnia, and there are few quantitative experimental studies on tropical species such as those of JAYATUNGA (1986) who investigated development times of Sri Lankan cladocerans. Authors working with tropical planktonic cladocerans such as GRAS \& SAINTJEAN (1978), MURUGAN (1975), JANA \& PAL $(1984,1985)$ and SAINT-JEAN \& BONOU (1994) fed their experimental animals with undefined lake or pond water. Quantitative studies are important as developmental durations provide the time element in growth and production determinations. It is of interest to know whether the largely small-sized tropical cladocerans habituated to narrow temperature ranges respond like warmedup temperate forms.

In this study, the influence of temperature and food concentration on the development times of three species of tropical cladocerans were studied experimentally, simultaneously and in 
combination, using species commonly found in the Amazon "varzea" lakes: Daphnia gessneri, Moina reticulata and Diaphanosoma sarsi, with third instars adult sizes of $1.5 \mathrm{~mm}, 0.8 \mathrm{~mm}$ and $1.2 \mathrm{~mm}$. These are the first such experimental studies on these species and in Latin America. The experimental temperatures ranged from $22-32^{\circ} \mathrm{C}$ - high temperatures for temperate species but spanning the full range experienced by tropical forms. Food levels were selected to cover a likely range from limiting to non-limiting food concentrations in the light of JAYATUNGA's (1986) prior experience with Sri Lankan cladocerans.

\section{MATERIALS AND METHODS}

\section{Stock cultures}

The cladoceran species studied were collected from Lake Jacaretinga in the Amazon State, Brazil, and transported to Royal Holloway College where they were maintained in 1 litrebeaker cultures using filtered Alderhurst Pond water at $27^{\circ} \mathrm{C}$, in an Astell Hearson incubator under a controlled 12 hour day/12 hour dark regime. These stock cultures of cladocerans were fed from stock cultures of the unicellular green alga, Scenedesmus acutus (Chlorophyceae, Chlorococcales) which were maintained in the exponential phase of growth by subculturing. In this condition, the food alga had cell dimensions of $10.34 \times 4.68 \mu \mathrm{m}$, cell volume of $102 \mu \mathrm{m}^{3}$ and cell carbon content of 11.78 pgC (ROCHA \& DUNCAN, 1985). For about three weeks prior to an experimental run, the stock cladoceran cultures were fed daily at a food level of $1.0 \mathrm{mgC} / \mathrm{L}$.

\section{Preparation of experimental food}

Samples of Scenedesmus acutus taken from the 5-9 day old liquid medium culture in exponential phase of growth were centrifuged to sediment the cells and washed twice in distilled water by re- centrifugation and re-suspension to remove the nutrient medium. The carbon content of the final concentrate of algae collected quantitatively was determined by the wetoxidation technique (COD) (MACKERETH et al., 1978). Food medium with a concentration of 1.0 $\mathrm{mgC} / \mathrm{L}$ was prepared by adding appropriate amounts of GFF-filtered pond water to the stock food suspension and other lower food levels were prepared by careful dilution of the $1.0 \mathrm{mgC} / \mathrm{L}$ suspension.

\section{Experimental chambers}

The experimental animals were reared for their whole life cycle, from neonates to third adult instar using two culture techniques both designed to provide a constant food concentration. One technique was the continuous flow system described by LAMPERT (1975) which provided a constant food concentration by slow replacement from a stirred known food supply at a rate controlled by a Watson-Marlow peristaltic pump (Figure 1). Six chambers of $100 \mathrm{ml}$ capacity and containing up to 20 individuals in each were 


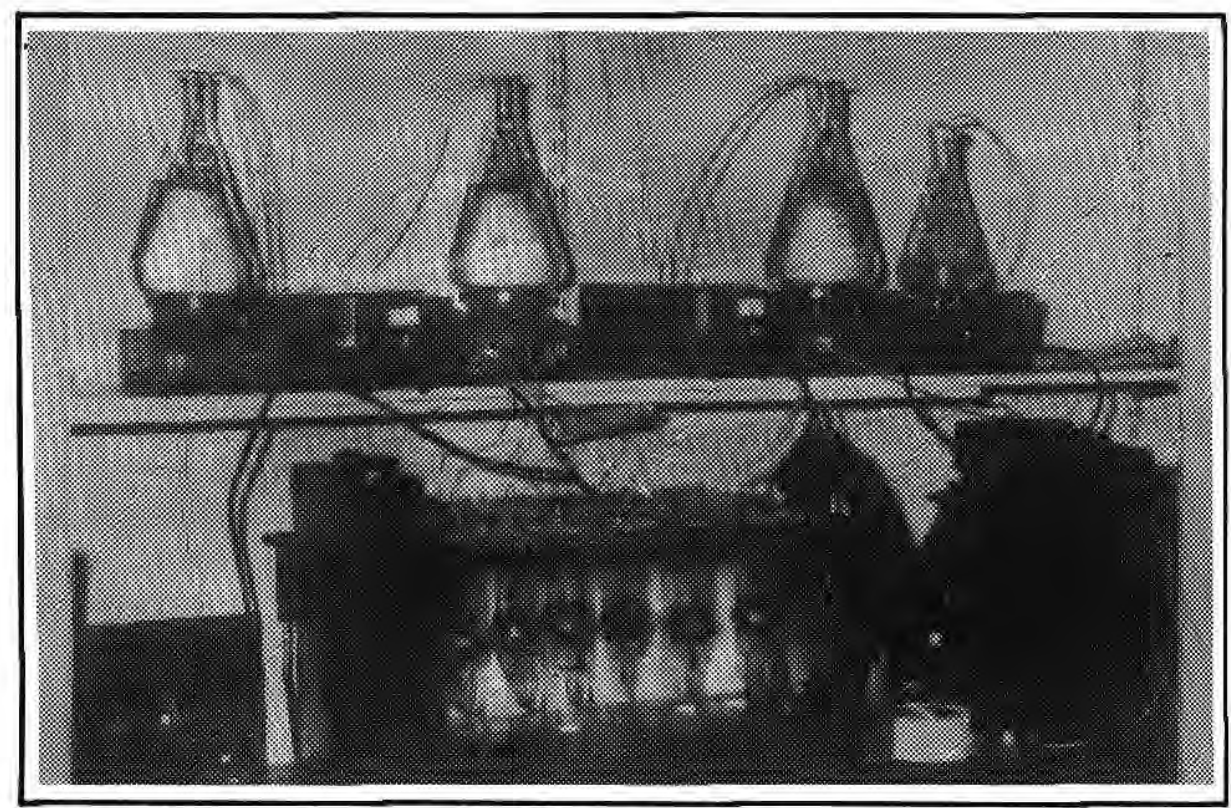

Figura 1. Continuons flow system food concentration and temperature effects on the life cycle characteristics of tropical cladocera Daplinia gessneri Herbst, Diaphanosoma sarsi Richard, Moina reticulata (Daday): I Development time. E.R. HARDY \& A. DUNCAN.

immersed in a temperature-controlled water-bath which maintained both the animals and the pumped food supply at the experimental temperature under natural daylight conditions. The other kind of experimental system adopted was batch culture using $250 \mathrm{ml}$ bottles whose food medium was changed daily. These bottles were turned on their short axes at $1 \mathrm{rpm}$ inside an Astell Hearson incubator with light and temperature control. Each bottle contained one individual and there were 4 replicates.

\section{Experimental design and procedure}

Daphnia gessneri was reared at three temperatures $\left(22^{\prime \prime}, 27^{\prime \prime}\right.$ and $32^{\prime \prime} \mathrm{C}$ ) and five food concentrations of Scenedesmus acutus $(1.0,0.5,0.25$,
0.1 and $0.05 \mathrm{mgC} / \mathrm{L}$ ), giving $15 \mathrm{ex}-$ perimental conditions; Diaphanosoma sarsi and Moina reticulata were cultured at the same food levels but only one temperature $\left(27^{\circ} \mathrm{C}\right)$. An additional food level $(0.03 \mathrm{mgC} / \mathrm{L})$ was tested in M. reticulata.

The life cycle studies at one temperature and five food concentrations were started with first instar neonates not older than 12 hours. A number of these (up to 20) were sorted, measured and placed in a chamber (Figure 1). Twice daily (at 8.00 and 17.00), the contents of each chamber was gently poured through a mesh which retained the animals and from which they could be removed by means of a large-bore pipette for quick examination. This involved date and time of observation, observation of state of health, mea- 
surement of length, determination of instar stage (carapaces) and counting the number of eggs or embryos in the brood pouches of adults. The duration of the adult instars gave embryonic durations. Animals were replaced into a clean flow-through chamber filled with freshly prepared food medium. With experienced handling, mortalities were almost nil amongst well-fed animals at the higher food concentrations but attained levels of 30\% (Daphnia) to $40 \%$ (Moina) at the lowest food levels $(0.05 \mathrm{mgC} / \mathrm{L})$ mostly during ecdysis when animals were especially vulnerable. Any accidental deaths or losses of animals were not replaced in flow cultures but neonates were replaced in batch cultures.

\section{RESULTS}

\section{Embryonic development}

Table 1 gives the mean durations of embryonic development in the three cladoceran species at each of the experiment food-temperature combina- tions in flow culture. These means, which were calculated from between 6-12 observations of all the individuals (up to 20) in one flow chamber, represent the time from release of oocytes from the ovary into the brood pouch to the release of first instars from the brood pouch, as detected by twice daily observation.

In D. gessneri with the most complete data set, it is clear that temperature has a powerful influence, doubling the embryonic duration with a $10^{\circ} \mathrm{C}$ decrease in temperature. There is also a food effect which results in a less pronounced prolongation of embryonic duration as food levels become more limiting. Moreover, the absence of $\mathrm{D}_{\mathrm{c}}$ values for $0.05 \mathrm{mgC} / \mathrm{L}$ at $27^{\circ} \mathrm{C}$ and for 0.10 and $0.05 \mathrm{mgC} / \mathrm{L}$ at $32^{\circ} \mathrm{C}$ is because all the juveniles died before maturing to an adult with adult instars. The shortest duration occurred at $32^{\circ} \mathrm{C}$ and $1.0 \mathrm{mgC} / \mathrm{L}$ and the most prolonged embryonic duration at $22^{\prime \prime} \mathrm{C}$ and $0.25 \mathrm{mgC} / \mathrm{L}$. There is a similar food effect on embryonic

Table 1. The duration of the embryonic development (D) of Daphnia gesseneri, Moina reticulata and Diaphanosoma sarsi in various combinations of temperature and food concentration in flow culture Duration in hours; mean \pm Standart deviation; number of observations in brackets.

\begin{tabular}{ccccccc}
\hline TEMPERATURE & \multicolumn{5}{c}{ FOOD CONCENTRATION $(\mathrm{mgC.L-1})$} \\
${ }^{\circ} \mathrm{C}$ & 1,0 & 0,5 & 0,25 & 0,1 & 0,05 & 0,03 \\
\hline Daphnia Gessneri & & & & & \\
22 & $50 \pm 4,6(12)$ & $56 \pm 10.6(12)$ & $63 \pm 11,5(12)$ & $58 \pm 16,3(9)$ & $54 \pm 10,0(7)$ & - \\
27 & $40 \pm 14,7(12)$ & $38 \pm 16,0(12)$ & $54 \pm 10,8(12)$ & $54 \pm 16,9(12)$ & $*$ & - \\
32 & $24 \pm 0,0(12)$ & $28 \pm 9,7(12)$ & $31 \pm 11,5(12)$ & $*$ & $*$ & - \\
Moina Reticulata & & & & & & \\
27 & $24 \pm 0,0(12)$ & $24 \pm 0,4(12)$ & $24 \pm 0,4(12)$ & $25 \pm 3,4(12)$ & $31 \pm 7,0(3)$ & $51 \pm 2,5(7)$ \\
Diaphanosoma Sarsi & & & & & & \\
27 & $24 \pm 0,0(12)$ & $29 \pm 10,4(9)$ & $34 \pm 12,4(9)$ & $40 \pm 11,4(6)$ & $44 \pm 20,4(11)$ & - \\
\hline
\end{tabular}

* The females did not complete three broods.

- Not tested. 
duration in $M$. reticulata and $D$. sarsi (Table 1). The embryonic duration of Moina at food levels 1.0 to $0.25 \mathrm{mgC} /$ $\mathrm{L}$ was constant at 24 hours and was both much shorter and less variable than those of the other two species (Table 1).

A comparison of the three species at one temperature shows considerable variation in embryonic durations at optimal food levels, that of the largest species (Daphnia) being much longer than the two smaller species. At the most severe food level of 0.05 $\mathrm{mgC} / \mathrm{L}$, the durations vary with species size ( $54 \mathrm{hr}, 1.5 \mathrm{~mm} ; 44 \mathrm{hr}, 1.2 \mathrm{~mm}$; $31 \mathrm{hr}, 0.8 \mathrm{~mm}$ ) (Table 1).

Table 2 gives the results of fitting a curvilinear regression of the form $\mathrm{D}=\mathrm{a} \cdot \mathrm{T}^{-\mathrm{b}}$ to describe, for Daphnia gessneri only, the relationship between embryonic development (D in hours) and temperature ( $\mathrm{T}$ in degrees Celsius) for each tested food level. Statistically significant regressions were obtained for food levels from 1.00 to $0.25 \mathrm{mgC} /$ $\mathrm{L}$ but not for $0.1 \mathrm{mgC} / \mathrm{L}(\mathrm{P}=0.25)$ or for $0.05 \mathrm{mgC} / \mathrm{L}$ in which the life cycle was completed under flow conditions at $22^{\circ} \mathrm{C}$ only (Table 1). Table 3 gives the results of covariance analysis of the three significant regressions in Table 2. This shows that the regression coefficients (slopes) were not significantly different but that the elevation of the regression for $0.25 \mathrm{mgC} / \mathrm{L}$ was significantly lower than the other two higher food levels.

An attempt was made to fit similar curvilinear regressions to quantify the relationship between embryonic development and food concentration for each tested temperature and species. Only one significant relationship was found, that for Diaphanosoma sarsi: $\ln \mathrm{Y}=3.19-0.179 \ln \mathrm{X}(\mathrm{df}=1,42$; $\mathrm{F}=130 ; \mathrm{P}=0.001$ ).

\section{Post-embryonic development}

The duration of post-embryonic development ( $=\mathrm{D}_{j}$ juvenile duration) was taken to extend from the release of neonates from the female's brood pouch (time 0 ) to the first appearance

Table 2. Curvilinear regressions relating the duration of embryonic development to temperature at various food concentrations for Daphnia gessneri in flow culture.

Regression equation lny $=\ln \mathrm{a}-\mathrm{b} \ln \mathrm{X}$

$\mathrm{Y}=$ duration of embryonic development in hours; $\mathrm{X}=$ temperature in " $\mathrm{C}$

$\mathrm{df}=$ degrees of freedom; $\mathrm{F}=$ variance ratio; $\mathrm{P}=$ level of significance

\begin{tabular}{cccccc}
\hline FOOD LEVEL (MgC. $\left.\mathrm{L}^{-1}\right)$ & In a & $\mathrm{b}$ & $\mathrm{df}$ & $\mathrm{F}$ & $\mathrm{P}$ \\
Daphnia gessneri & & & & & \\
1,0 & 9,76 & $-1,88$ & 1,29 & 27,9 & 0.001 \\
0,5 & 9,86 & $-1,90$ & 1,32 & 87,6 & 0.001 \\
0,25 & 10,03 & $-1,88$ & 1,31 & 5,7 & 0.025 \\
0,1 & 8,87 & $-1,54$ & 1,18 & 2,6 & 0.25 \\
0,05 & $*$ & & & & \\
\hline
\end{tabular}

* regression coud not be calculated 
Table 3. Covariance analysis of the significant regressions of duration of embryonic development on temperature at various food levels for Daphnia gessneri. The regression coefficients were compared by the SS-STP test and the differences between elevations by the S-N-K test. Regression coefficients and means underlined are not significantly different at $\mathrm{P}=0.05$ level; Group numbers are given in ascending order of magnitude.

\section{Comparisons of}

Slopes

\begin{tabular}{|c|c|c|c|c|c|c|}
\hline $\begin{array}{c}\text { FOOD LEVEL } \\
\text { mgC. } L^{-1}\end{array}$ & GROUP & REGRESSION COEF. \pm SE & df & $\mathrm{F}$ & $P$ & SS-STP \\
\hline 1,0 & 1 & $-1.88 \pm 0.30$ & 2,95 & 0.001 & 0,99 & 123 \\
\hline 0,5 & 2 & $-1.90 \pm 0.33$ & & & & \\
\hline 0,25 & 3 & $-1.88 \pm 0.33$ & & & & \\
\hline & & & \multicolumn{2}{|c|}{$\begin{array}{c}\text { Copararison of } \\
\text { Elevations }\end{array}$} & & \\
\hline $\mathrm{mgC} \cdot \mathrm{L}^{-1}$ & GROUP & ADJUSTED MEAN+SE & df & $\mathrm{F}$ & $P$ & S-N-K \\
\hline 1,0 & 1 & $3.59 \pm 0.15$ & 2,98 & 8.61 & 0.000 & 123 \\
\hline 0,5 & 2 & $3.64 \pm 0.15$ & & & & \\
\hline 0,25 & 3 & $3.85 \pm 0.15$ & & & & \\
\hline
\end{tabular}

of the primiparous female carrying her male. In practice, the actual moment first brood. This was easiest to observe of release of neonates or oocytes was on individuals in batch culture. Thus only rarely observed but were rethe duration of the juvenile stage also corded at the next observation time. estimates the age of the primipara fe- The presence of an ecdysed carapace

Table 4. Duration of post-embryonic development (hours) to primipara and of instars (in parenthesis) attained in various combinations of food and temperature in, Daphnia gessneri. Moina reticulata and Diaphanosoma sarsi. $\mathrm{N}=4$. Batch culture.

\section{TEMPERATURE ${ }^{\circ} \mathrm{C} \quad$ FOOD CONCENTRATION $\left(\mathrm{mgC.L} \mathrm{L}^{-1}\right)$}

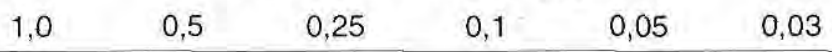

Daphnia gessneri

22

27

32

Moina reticulata

27

Diaphanosoma sarsi

$\begin{array}{ccccc}177 \pm 11.4 & 186 \pm 12.0 & 186 \pm 20.7 & 207 \pm 35.8 & 240 \pm 56.7 \\ (\mathrm{~V}-\mathrm{VII}) & (\mathrm{VI}-\mathrm{VII}) & (\mathrm{VIII}) & (\mathrm{VIII}) & (\mathrm{VII}-\mathrm{X}) \\ 174 \pm 12.0 & 156 \pm 16.9 & 162 \pm 12.0 & 192 \pm 0.0 & 198 \pm 22.8 \\ (\mathrm{~V}-\mathrm{V} I I) & (\mathrm{V}-\mathrm{VII}) & (\mathrm{VI}-\mathrm{VII}) & (\mathrm{VIII}-\mathrm{IX}) & (\mathrm{IX}) \\ 132 \pm 0.0 & 156 \pm 0.0 & 162 \pm 12.0 & 207 \pm 18.0 & 246 \pm 53.2 \\ (I V-V I) & (\mathrm{V} . \mathrm{VI}) & (\mathrm{V}-\mathrm{VI}) & (\mathrm{VI}-\mathrm{VII}) & (\mathrm{VII}-\mathrm{VIII})\end{array}$

$54.0 \pm 0.0$

(III)

$48.0 \pm 0.0$

$48.0 \pm 0.0$

$48.0 \pm 0.0$

$90.0 \pm 12.0$
(III)
(III)
(III-IV)
(III)
(IV-V)

(III)
(III-IV)
(IV) (IV-V)
(V)
(V-VI) 
accompanies the release of the first instar neonates and permits the identification of the instar stage of the female.

Table 4 gives the mean post-embryonic durations $( \pm$ SD) for the three species at the same temperature and food level combinations as before but taken from the batch culture experiments. In D. gessneri, there is a gen- eral pattern of prolongation of postembryonic development with decrease in temperature, with some variability at the higher food levels. in Table 5, three significant curvilinear regressions of duration on temperature could be fitted to the data for the top food levels but not for 0.1 and $0.05 \mathrm{mgC} /$ L. Covariance analysis in Table 6 of the three significant regressions

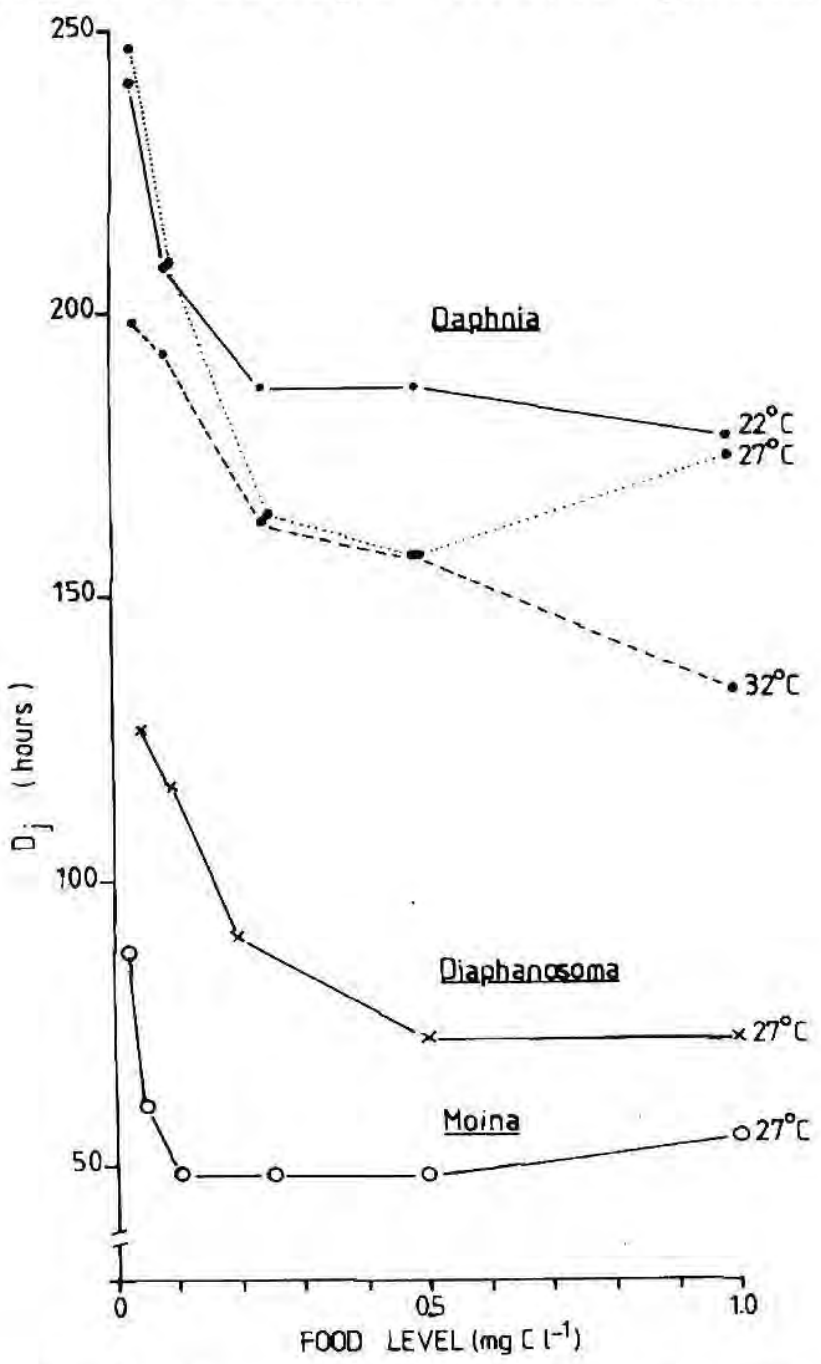

Figura 2. The effect of food concentration on the mean duration of postembryonic development of $D$. gessiri, $D$. sarsi and $M$. reticulata at various temperatures. 
showed that neither the slopes $(\mathrm{P}=0.24)$ nor the elevations $(\mathrm{P}=0.26)$ of these differed. This means that temperature influences juvenile duration in Daphnia gessneri in the higher food levels but not in the lower ones.

The striking effect in Table 4 is the prolongation of the post-embryonic duration in the lower food levels from $0.1 \mathrm{mgC} / \mathrm{L}$ downwards. in $D$. gessneri, from $0.25 \mathrm{mgC} / \mathrm{L}$ downwards in $D$. sarsi and from $0.05 \mathrm{mgC} /$ $\mathrm{L}$ downwards in $M$. reticulata. Table 7 gives the results for fitting curvilinear regression of juvenile duration on food concentration at each tested temperature. It proved possible to fit significant regressions for $D$. gessneri at all three temperatures and for $D$. sarsi at $27^{\circ} \mathrm{C}$ but not for $M$. reticulata $(\mathrm{P}=0.14)$. This last species shows a rather different pattern of response with a constant juvenile duration of 48 hours for food levels from 0.5 to $0.1 \mathrm{mgC} / \mathrm{L}$ (Table 4). However, a significant regression could be fitted to the data for food levels $0.1,0.05$ and
$0.03 \mathrm{mgC} / \mathrm{L}$; this was $\ln \mathrm{Y}=1.26$ $1.08 \ln \mathrm{X}$ (d.f. 1,$7 ; \mathrm{F}=249 ; \mathrm{P}=<0.001$ ).

Figure 2 illustrates these relationships between $\mathrm{D}_{\mathrm{j}}$ and food concentration in the three cladocerans and shows several interesting features. One is a body size effect, namely that post-embryonic duration was longest in the largest species $D$. gessneri (3rd instar adult size, $1.5 \mathrm{~mm}$ ), shortest in the smallest species $M$. reticulata $(0.8 \mathrm{~mm})$ and was intermediate in $D$. sarsi $(1.2 \mathrm{~mm})$. This figure also shows that the food threshold level at which food limitation starts (= marked prolongation of $\mathrm{D}_{\mathrm{i}}$ ) is much lower in Moina $(<0.1 \mathrm{mgC} / \mathrm{L})$, higher in Diaphanosoma (0.25 mgC/L) than in Daphnia (at 0.1 $\mathrm{mgC} / \mathrm{L}$ ) in a manner which parallels embryonic duration. The aberrant point at $27^{\circ} \mathrm{C} / 1.0 \mathrm{mgC} / \mathrm{L}$ in Figure 2 comes from a high degree of variability in individual $\mathrm{D}_{\text {, values and general }}$ lower "fitness" ("difficult" ecdysis) in what seems to be "excess" food for this species.

Table 4 also gives the instar stage of the primiparous females for each

Table 5. Curvilinear regressions relating the duration of post-embryonic development to temperature at various foog concentration for Daphnia gessneri in batch culture.

Regression equation $\ln \mathrm{Y}=\ln \mathrm{a}-\ln \mathrm{X}$

$\mathrm{Y}=$ post-embryonic development in hours; $\mathrm{X}=$ temperature in ${ }^{\circ} \mathrm{C}$ $\mathrm{df}=$ degrees of freedon; $\mathrm{F}=$ variance ratio; $\mathrm{P}$ level of significance

$\begin{array}{cccccc}\begin{array}{c}\text { FOOD CONCENTRATION } \\ \left(\text { mgC. } L^{-1}\right)\end{array} & \text { In a } & b & \text { df } & F & P \\ \text { Daphnia gessneri } & 7,55 & -0,75 & 1,10 & 19,75 & 0.001 \\ 1 & 6,67 & -0,47 & 1,10 & 9,96 & 0.010 \\ 0,5 & 6,34 & -0,37 & 1,10 & 4,72 & 0.05 \\ 0,25 & 5,25 & 0,01 & 1,8 & 0,006 & 0.94 \\ 0,1 & 5,01 & 0,09 & 1,10 & 0,059 & 0.81 \\ 0,05 & & & & & \end{array}$


temperature-food condition. The general pattern of response in $D$. gessneri is that the females became primiparous at instar IV-V at the higher temperatures and higher food levels but were not able to produce a brood of young until instars VIII-IX-X at lower temperatures and low food levels. In both Diaphanosoma and Moina at $27^{\circ} \mathrm{C}$, primiparous females appeared at instar III in the highest food levels but at later and later instars with declining food levels. Diaphanosoma matured at instars $\mathrm{V}$-VI in $0.05 \mathrm{mgC} / \mathrm{L}$ and Moina at instar IV in $0.03 \mathrm{mgC} / \mathrm{L}$. Only in Moina, the pattern of response differed in that there was no change in the duration of postembryonic development until they were reared in food levels of $0.05-0.03 \mathrm{mgC} / \mathrm{L}$. In general, the response to severe conditions of both high temperature and low food level appears to involve delaying the primipara's stage of development and, inevitably, increasing her age.

Table 8 gives values of the ratio for $D_{j} / D_{c}$ for all three species reared in batch culture at the comparable temperature of $27^{\circ} \mathrm{C}$. The pattern shown by Moina reticulata is the simplest - the ratio increases with greater prolongation of $\mathrm{D}_{\mathrm{i}}$ as food levels became limiting and, as shown in Table 4, this is associated with an increased number of juvenile instars from III to V. The pattern of D/ $D_{c}$ with food level is more complex in the other two species: the lowest ratio occurs at $0.25 \mathrm{mgC} / \mathrm{L}$ and it increases on either side of this food level. The increased ratios at food levels lower than $0.25 \mathrm{mgC} / \mathrm{L}$ are due to food limitation, together with associated increased number of juvenile instars, as in Moina: from V to IX in Daphnia and from IV to VI in Diaphanosoma. We do not know the causes of the larger ratios in food levels larger than 0,25 $\mathrm{mgC} / \mathrm{L}$ in these two species, except that these are not associated with increased number of juvenile instars (Table 4). In general, the replicated individuals reared in the food levels of 0.5 and $1.0 \mathrm{mgC} / \mathrm{L}$ were more variable in $\mathrm{D}_{\mathrm{j}}$ and $\mathrm{D}_{\mathrm{c}}$ and less "fit".

The relationship of post-embryonic duration to both temperature and food concentration was examined for $D$. gessneri by means of multiple regression analysis (Table 9). The best fit to the data was obtained using the equation $1 / \mathrm{D}_{\mathrm{j}}=\mathrm{a}-\mathrm{b}, 1 / \mathrm{T}+\mathrm{c} \cdot \mathrm{InF}$. An analysis of the variance associated with food concentration was three times greater than that due to temperature.

\section{DISCUSSION}

The three species studied are all truly tropical (Lake Jacaretinga, $3^{\prime \prime} \mathrm{S}$ ). Daphnia gessneri was first described in 1965 , has been recorded only from northern South America and is the only Daphnia species recorded in the well-worked Lake Jacaretinga and its other localities. Both Moina and Diaphanosoma are commoner genera in the South America, particularly in the turbid Amazonian lakes, but little is known about their distribution elsewhere.

The main findings of this study are that the quantity of food is as im- 
portant factor as temperature for the duration of development of tropical planktonic cladocerans as of temperate species. There is a significant prolongation of development as either temperature or food level decreases as well as temperature-food synergistic effects reported by ORCUTT \& PORTER, (1984). These effects are shown for D. gessneri, Diaphanosoma sarsi and Moina reticulata for the first time.

\section{Embryonic duration}

Temperature was the main factor controlling the embryonic duration of Daphnia gessneri reared on the higher food levels, with a halving of the duration with a $10^{\prime \prime} \mathrm{C}$ increase in temperature (Table 1). However, at lower food levels there is some evidence of a food-level effect on $D_{c}$ shown by longer $\mathrm{D}_{\mathrm{c}}$ values which caused nonsignificant regressions of $\mathrm{D}_{\mathrm{c}}$ on temperature or inability to measure $\mathrm{D}_{c}$ in tested food levels under flow conditions (Tables 1,2). Both of these effects may be due to the poor nutritional condition of the mother under food limiting condition, particularly at the two higher temperatures. ORCUTT \& PORTER (1984), who quantified their experimental food levels $(0.02$ to $2.0 \mathrm{mgC} / \mathrm{L})$, have also found a significant food-level effect as well as synergistic temperature-food effects on embryonic development of the Georgian (USA) Daphnia parvula. Compared with Daphnia, the foodlevel effect on $\mathrm{D}_{\mathrm{c}}$ of Moina reticulata and Diaphanosoma sarsi was both

Table 6. Covariance analysis of the regressions comparing the duration of post-embryonic development on temperature at different food concentrations for Daphnia gessneri. The regression coefficient were compared by the SS-Stp test and difference between elevations by the S$\mathrm{N}-\mathrm{K}$ test. Regression coeficients and mens underlined are not significantly different at $\mathrm{P}=0.05$ level.

Regression equation $\ln \mathrm{Y}=\ln \mathrm{a}-\mathrm{b} \ln \mathrm{X}$

$\mathrm{Y}=$ duration of post-embryonic development in hous; $\mathrm{X}=$ food concentration in $\mathrm{mgC} . \mathrm{L}^{-1}$; $\mathrm{df}=$ degrees of freedom; $\mathrm{F}=$ variance ratio $; \mathrm{P}=$ level of significance

COMPARISON

OF SLOPES

\begin{tabular}{|c|c|c|c|c|c|c|}
\hline $\begin{array}{c}\text { FOOD LEVEL } \\
\mathrm{mgC}^{-L^{-1}}\end{array}$ & GROUP & REGRESSION COEFF. \pm SE & df & $\mathrm{F}$ & P & SS-STP \\
\hline 1.0 & 1 & $-0.75 \pm 0.17$ & 2,30 & 1,45 & 0,24 & 321 \\
\hline 0.5 & 2 & $-0.47 \pm 0.15$ & & & & \\
\hline 0.25 & 3 & $-0.37 \pm 0.17$ & & & & \\
\hline & & & \multicolumn{2}{|c|}{$\begin{array}{l}\text { COMPARISON } \\
\text { OF ELEVATIONS }\end{array}$} & & \\
\hline $\mathrm{mgC} \cdot \mathrm{L}^{-1}$ & GROUP & ADJUSTED MEAN $\pm S E$ & df & $\mathrm{F}$ & $P$ & S-N-K \\
\hline 1.0 & 1 & $5.07 \pm 0.05$ & 2,33 & 1.39 & 0.26 & 123 \\
\hline 0.5 & 2 & $5.10 \pm 0.05$ & & & & \\
\hline 0.25 & 3 & $5.13 \pm 0.05$ & & & & \\
\hline
\end{tabular}


Table 7. Curvilinear regressions relating the duration of post-embryonic development to food concentration at various temperature for Daphnia gessneri, Moina reticulata and Diaphanosoma sarsi in batch culture

Regression equation $\ln \mathrm{Y}=\ln \mathrm{a}-\mathrm{b} \ln \mathrm{X}$

$\mathrm{Y}=$ post-embryonic development in hours; $\mathrm{X}=$ food concetration in $\mathrm{mgC.} \mathrm{L}^{-1}$

\begin{tabular}{cccccc}
\hline TEMPERATURE ${ }^{\circ} \mathrm{C}$ & In a & $\mathrm{b}$ & $\mathrm{df}$ & $\mathrm{F}$ & $\mathrm{P}$ \\
\hline Daphnia gessneri & & & & & \\
22 & 5.14 & -0.087 & 1,18 & 8.63 & 0.008 \\
27 & 5.07 & -0.060 & 1,16 & 6.89 & 0.018 \\
32 & 4.89 & -0.160 & 1,18 & 50.70 & 0.000 \\
Moina reticulata & & & & & \\
27 & 43.38 & -8.05 & 1,18 & 3.22 & 0.14 \\
Diaphanosoma sarsi & & & & & \\
27 & 4.20 & -0.21 & 1,17 & 45.1 & 0.000 \\
\hline
\end{tabular}

larger and started at lower food levels (Table 1). JAYATUNGA (1986), who is the only other worker on tropical cladocerans using defined food levels, found a significant prolongation of embryonic duration in the Sri Lankan Moina micrura at $0.05 \mathrm{mgC} / \mathrm{L}$ ) in both $27^{\circ} \mathrm{C}$ and $32^{\prime \prime} \mathrm{C}$ ).

\section{Postembryonic duration}

The dependence of juvenile duration on food concentration has been shown for all three cladoceran species but how temperature affects this response could be demonstrated only for Daphnia.

The pattern of response in Daphnia gessneri is that the juvenile phase prolongation was continuous as food level declined, was greatest at the two lower food levels and most severe at the highest temperature. This pattern of $D_{j}$ on food level was statistically significant at each temperature (Table 7), there is no statistical difference between regressions for $D_{i}$ on tempera- ture (Table 6) and the multiple regression in Table 9 shows that the variance associated with food concentration was three times greater than that due to temperature. The most severe food limitation occurred in the combination of low food and high temperature which represents extreme conditions for a tropical species whose normal temperature range in the field is a few degrees either side of $27^{\circ} \mathrm{C}$.

A similar pattem of response to that of Daphnia described above was shown by Diaphanosoma sarsi at $27^{\circ} \mathrm{C}$. Here too a significant regression of $\mathrm{D}^{\mathrm{i}}$ on food was obtained and the greatest prolongation of the juvenile phase occurred at the lowest food of $0.05 \mathrm{mgC} / \mathrm{L}$. Only in Moina reticulata at $27^{\circ} \mathrm{C}$ was there no significant relationship between $\mathrm{D}_{\mathrm{j}}$ and food concentration including all six tested levels. The $\mathrm{D}_{\mathrm{i}}$ remained constant down to $0.1 \mathrm{mgC} / \mathrm{L}$ and a significant relationship could only be obtained from the three lowest food levels. Moina reticulata is noteworthy in being the only tested species whose juveniles survived to maturity at 0.03 
Table 8. The mean values of the ratio $\mathrm{D}_{\mathrm{i}} / \mathrm{D}_{\mathrm{c}}$ and standard deviation for Daphnia gessneri, Moina reticulata and Diaphanosoma sarsi in batch culture. Values in brackets gives the number of observations.

\begin{tabular}{|c|c|c|c|c|c|c|}
\hline \multicolumn{2}{|l|}{$\mathrm{T}^{\circ} \mathrm{C}$} & \multicolumn{5}{|c|}{ FOOD CONCENTRATION ou $\mathrm{mgC}, \mathrm{L}^{-1}$} \\
\hline Species & 1.00 & 0.50 & 0.25 & 0.10 & 0.05 & 0.03 \\
\hline \multicolumn{7}{|c|}{ Daphnia gessneri } \\
\hline $27^{\circ} \mathrm{C}$ & $\begin{array}{c}3.01 \\
\pm 1.55(5)\end{array}$ & $\begin{array}{c}2.16 \\
\pm 0.52(5)\end{array}$ & $\begin{array}{c}1.71 \\
\pm 0.20(6)\end{array}$ & $\begin{array}{c}3.13 \\
\pm 0.87(3)\end{array}$ & $\begin{array}{c}2.70 \\
\pm 0.86(4)\end{array}$ & - \\
\hline \multicolumn{7}{|c|}{ Diaphanosoma sarsi } \\
\hline $27^{\circ} \mathrm{C}$ & $\begin{array}{c}2.75 \\
\pm 0.58(4)\end{array}$ & $\begin{array}{c}2.71 \\
\pm 0.47(3)\end{array}$ & $\begin{array}{c}2.07 \\
\pm 0.53(3)\end{array}$ & $\begin{array}{c}3.19 \\
\pm 0.0(2)\end{array}$ & $\begin{array}{c}2.83 \\
\pm 0.89(4)\end{array}$ & - \\
\hline \multicolumn{7}{|c|}{ Moina reticulata } \\
\hline $27^{\circ} \mathrm{C}$ & $\begin{array}{c}1.17 \\
\pm 0.0(3)\end{array}$ & $\begin{array}{c}1.17 \\
\pm 0.0(3)\end{array}$ & $\begin{array}{c}1.42 \\
\pm 0.0(3)\end{array}$ & $\begin{array}{c}1.36 \\
\pm 0.44(3)\end{array}$ & $\begin{array}{c}1.99 \\
\pm 0.44(3)\end{array}$ & $\begin{array}{c}1.97 \\
\pm 0.0(3)\end{array}$ \\
\hline
\end{tabular}

$\mathrm{mgC} / \mathrm{L}$. Daphnia parvula can complete her life cycle in a food concentration as low as $0.02 \mathrm{mgC} / \mathrm{L}$, according to ORCUTT \& PORTER (1984).

\section{Food thresholds}

In the process of food limitation, there are two food threshold levels : that at which onset of food limitation starts (= beginning of developmental prolongation) and that below which maturation of juveniles becomes impossible. This defines the concentration range of food limitation. At the comparable temperature of $27^{\circ} \mathrm{C}$, these three species differed both these food threshold levels. They were lowest in Moina reticulata and higher in the other two species. This is a finding that is opposite to ROMANOVSKY's (1985) prediction that ruderal species like Moina have "higher food thresholds" than competitor species like Daphnia and Diaphanosoma. Temperature also affected food threshold levels at which juveniles could not complete their maturation: for $D$. gessneri, these were $<0.25 \mathrm{mgC} / / \mathrm{L}$ at $32^{\circ} \mathrm{C},<0.1^{\circ} \mathrm{mgC} / \mathrm{L}$ at $27^{\circ} \mathrm{C}$ and $<0.05 \mathrm{mgC} / \mathrm{L}$ at $22^{\circ} \mathrm{C}$. The absolute concentration of these tropical food thresholds for development are similar to those reported for temperate

Table 9. Parametrs of the multiple regressions relating the effect of food concentration and temperature on the duration of post-embryonic development of Daphnia gessneri.

Regression equation: $1 / \mathrm{D}_{\mathrm{i}}=\mathrm{a}-\mathrm{b}, 1 / \mathrm{T}+\ln \mathrm{F}$

$\mathrm{D}_{\mathrm{j}}=$ juvenile duration in hours; $\mathrm{T}=$ temperature in ${ }^{\circ} \mathrm{C} ; \mathrm{F}=$ food concentration in $\mathrm{mgC} . \mathrm{L}^{-1}$

$\mathrm{df}=$ degress of fredom; $\mathrm{F}=$ variance ratio; $\mathrm{P}=$ level of significance.

Daphnia gessneri

Due to food concentration

$\begin{array}{cccccc}a & b & c & \text { df } & F & P \\ 0.0087 & -0.611 & 0.00054 & 2,55 & 24.37 & 0.001 \\ & & & & 36.39 & 0.001\end{array}$

Due to temperature 
and other tropical species (ROCHA, 1983; ORCUTT \& PORTER, 1984, JAYATUNGA, 1986).

\section{Numbers of juvenile instars}

LEI \& ARMITAGE (1980) suggest that an increase in postembryonic development time could arise either from an increase in the duration of the individual juvenile instars without an increase in their number or from an increase in the number of juvenile instars without an increase in their individual duration or from an increase in both duration and numbers of juvenile instars. From our evidence in Table 4 , all three species lengthen their juvenile phase mainly by adding more juvenile instars and that this occurs only at limiting food levels. However, at $32^{\circ} \mathrm{C}$ Daphnia gessneri is capable of increasing both duration and numbers of juvenile instars as the food level is changed from $1.0 \mathrm{mgC} / \mathrm{L}$ to $0.05 \mathrm{mgC} / \mathrm{L}$.

\section{The ratio $\mathrm{D}_{\mathrm{j}} \mathrm{D}_{\mathrm{e}}$}

BONOU et al. (1991) and SAINTJEAN \& BONOU (1994) show very clearly the relationship between the number of juvenile instars and the size of the $\mathrm{D}_{1} / \mathrm{D}_{\mathrm{c}}$ ratio in Moina micrura from fish ponds in the Ivory Coast . Both papers show that in the $30^{\circ} \mathrm{C}$ experiments all individuals attained the primipara stage with 2 instars and a $D_{1} / \mathrm{D}_{\mathrm{c}}$ ratio of 0.98 in 1991 paper and 0.89 in the 1994 paper. Whereas there were 2-instar, 3-instar and 4-instar primiparas present in the $26^{\circ} \mathrm{C}$ experiments, with $\mathrm{D}_{1} / \mathrm{D}_{\mathrm{c}}$ ratios of 1.12 and 1.03 , respectively. From our results in Table 6, these were well-fed Moina but there was probably some difference be- tween the food conditions in these two periods as well as a temperature difference. In general, the response to food limitation appears to involve delaying the primipara's development stage thus, inevitably, increasing her age.

\section{Body size effect}

Within the three tropical cladocerans studied here, the smallest Moina reticulata attained maturity in the fastest time at all food levels and under similar conditions compared with Diaphanosoma sarsi and Daphnia gessneri, both larger animals.

This confirms its classification by ROMANOVSKY (1985) and SAINT JEAN \& BONOU (1994) as an opportunistic ruderal species.

It provides some evidence to support the hypothesis that body size and duration of postembryonic development of cladocerans are positively related (HALL ET A., 1976; ALLAN \& GOULDEN, 1980).

\section{ACKNOWLEDGMENTS}

We wish to thank the National Research Council of Brazil (CNPq) for financial support to $\mathrm{EH}$ during her earlier postgraduate research and CAPES and the National Institute for Amazon Research (INPA) for funding a leave of absence during which this paper could be written at Royal Holloway College University of London using facilities for which we also give thanks.

\section{Literature Cited}

ALLAN, J.D; GOULDEN, C.E. 1980. Some aspects of reproductive variation among freshwater zooplankton. In: Evolution and Ecology of Zooplankton Communities (ed, Kerfoot, W.C.),pp.388-410. 
American Society of Limnology and Oceanography Special Symposium.

BONOU, C.A.; PAGANO, M.; SAINT-JEAN,

L. 1991. Developpement et croissance en poids de Moina ( $c f$ ) micnura et de Mesocvclops ogumnus dans un milieu saumatre tropical: les etangs de pisciculture de Layo (Cotes-d'lvoire). Rev. Hydrobiol. trop. 24(4):287-303.

BOTTRELL, H.H. 1975. The relation between temperature and duration of egg development in some epiphytic Cladocera and Copepoda from the River Thames, Reading, with a discussion of temperature functions. Oecologia (Berl.), 18: 63-84.

BOTTRELL, H.H.;DUNCAN,A.; GLIWICZ, Z.M.; GRYGIEREK,E.; HERZIG, A.; HILLBRICHT-ILKOWSKA, A.; KURASAWA, H. LARSSON, P.; WEGLENSKA,T. 1976. A review of some problems in zooplankton production studies. Norwegian Journal Zoology, 24,419-456.

DE BERNARDI, R.; LACQUA, P.; SALDAVINI, E. 1978. Effects of temperature and food on development times and growth in Daphnia obtusa Kurz, and Simocephalus vetulus (O.F. Muller) (Crustacea, Cladocera). Mem. Ist. Ital.Idrobiol. 36: 171-191.

DUNCAN, A. 1989. Food limitation and body size in the life cycles of planktonic rotifers and cladocerans. Hydrobiologia 186/187:11-28.

ESSLOVA,M. 1959. Embryonic development of parthenogenetic eggs of Daphnia pulex. Acta Soc.Zool.Bohem. 23,80-88.

GRAS,R.; SAINT-JEAN,L. 1976. Duree du developpement embryonnaire chez quelques especes de cladoceres et de copepodes du lac Tchad.Cah. O. R. S . T . O . M . s e r . Hydrobiologia, X,4:233-254.

GRAS,R.; SAINT-JEAN,L. 1978. Duree et caracteristiques du developpment juvenile de quelques cladoceres du lac Tchad. Cah. O.R.S.T.O.M., ser. Hydrobiologia. XII, 2:119-136.
HALL, D.J. 1964. An experimental approach to the dynamics of a natural population of Daphnia galeata mendotae. Ecology. 45: 94-112.

HALL,D.J.; THRELKELD,S.T.; BURNS,C.W.; CROWLEY,P.H. 1976. The size efficiency hypothesis and the size structure of zooplankton communities. Ann.Rev.Ecol.Syst. 7:177-208.

HERZIG,A. 1984. Temperature and life cycle strategies of Diaphanosoma brachiurum: An experimental study on development, growth and survival. Archivum Hydrobiologie, 101,(1/2) 143-178

HRBACKOVA-ESSLOVA. M. 1962. Postembryonic development of cladocerans. 1. Daphnia pulex group. Vestn.Cesk.Spol.Zool. 26:212-233.

HRBACKOVA-ESSLOVA, M. 1963. The development of three species of Daphinia in the surface water of the Slapy Reservoir.Int. Revue ges. Hydrobiol. 48:325-333.

INGLE,Z; WOOD,T,; BANTA, A.M. 1937. A study of longevity, growth, reproduction, and heart rate in Daphnia longispina as influenced by limitation in quantity of food. Journal of Experimental Zoology; 76:325-352.

JANA,B.B.; PAL,G.P. 1984. The life history parameters of Diaphanosoma excisum (Cladocera) grown in different culturing media. Hydrobiologia, 118,205-212.

JANA,B.B.; PAL,G.P. 1985. The life history parameters of Moina micrura (Kurz) grown in different culturing media. Waler Res.19, 863-867.

JAYATUNGA,Y.N.A, 1986. The influence of food and temperature on the life cucle characteristics of mopical cladoceran species from Kalawewa Reservoir; Sri Lanka. Ph.D Thesis. University of London, 410p.

KANKAALA,P; WULFF,F, 1981. experimental studies on temperature dependent embryonic and postembryonic developmental rates of Bosmina longispina maritima (Cladocera) in the Baltic. Oikes, 36,137-146. 
KORINEK, V. 1970. The embryonic and postembryonic development of Daphnia hyalina from Lake Maggiore. Mem.ist Ital.Idrobiol. 26,85-95

LAMPERT,W. 1875. A laboratory system for the cultivation of large numbers of Daphniae under controlled conditions. Archiv Hydrobiologie, suppl.48:138-140.

LEI, C.; ARMITAGE,K.B. 1980. Growth, development and body size of field and laboratory populations of Daphnia ambigua. Oikos, 35,31-48.

LEVEQUE, C.; SAINT-JEAN,L. 1983. Secondary production (zooplankton and benthos). In: Lake Chad. (eds. J.P. Carmouze, J.R. Durand and C.Leveque), pp 385-425. Dr. W. Junk Publishers, The Hague.

MACKERETH,F.J.H;

HERON,J;

TALLING,JF. 1978. Water Analysis: Some revised methods for Limnologists. Freshwater Biological Association, $36,120 \mathrm{pp}$.

MAGADZA,C.H.D. 1977. Determination of development period at various temperatures in a tropical cladoceran Moina dubia. De Gueme and Richard Transactions Rhod. Scientist Association. 59, 6:41-45.

MUNRO,I.G,; WHITE, R.W.G. 1975. Comparison of the influence of temperature on the egg development and growth of Daphnia longispina O.F. Muller (Crustacea: Cladocera) from two habitats in Southern England. Oecologia (Berl.). 20,157-166.

MURUGAN,N.1975. Egg production, development and growth in Moina micrura Kurz (1874) (Cladocera:Moinidae). Freshwat.Biol. 5:245-250
ORCUTT,J.D.: PORTER,K.G. 1984. The synergistic effects of temperature and food concentration on life history parameters of Daphnia parvula. Oecologia (Berl.), 63,300-306.

ROCHA,O. 1983. The influence of food-temperature combinations on the duration of development, body size, growth and fecundity of Daphnia species. Ph.D Thesis. University of London, $337 \mathrm{pp}$.

ROCHA,O.; DUNCAN,A. 1985. The relationship between cell carbon and cell volume in freshwater algal species used in zooplanktonic studies. Journal of Plankton Research, 7(2):279-294.

ROMANOVSKY,Y.E. 1985. Food limitation and life history strategies in cladoceran crustaceans, Arch.Hydrobicl. Beih. Ergebn.Limnol.21:363-372

SAINT-JEAN,L.; BONOU,C.A. 1994. Growth, Production and Demography of Moina micrura in Tropical Brackish Fish Ponds (Layo, Ivory Coast). Hydrobiologia, 272,125-146.

VIJVERBERG,J. 1980. Effect of temperature in laboratory studies on development and growth of Cladocera and Copepoda from Tjeukemeer, The Netherlands. Fresh.Biol. 10:317-340.

WEGLENSKA,T. 1971. The influence of various concentrations of natural food on the development, fecundity and production of planktonic crustacean filtrators. Ekologic Polska, 19,427-473. 